\title{
Presidents, Precedents and the Use of Military Force
}

\author{
DAVID MERVIN
}

In the late summer of 1996 Iraqi troops moved into the Kurdish "safe haven" in Northern Iraq, thereby triggering a crisis of national security for the United States. Unsurprisingly, this incident led to speculation in the media about the nature of President Clinton's response. Would he be able to meet this test of his leadership? What form would any military action take? Would it be strong enough, or would it be an overreaction? In the event, the president ordered two cruise missile strikes against Iraqi defence installations and substantially extended the no-fly zone in Southern Iraq set up after the Gulf War. These actions were the subject of debate in the United States Senate and, after some partisan wrangling, and a few rumbles of complaint about inadequate consultation, a nonbinding resolution endorsing the missile strikes was approved by a vote of $9^{6-}$. . But, as was noted by the press, "none of this really mattered because such 'sense of the Senate' resolutions have no binding effect and are largely ignored, even inside the Beltway."

What was striking about this incident was that throughout the crisis the United States Congress was little more than a bystander. Inevitably all eyes turned to the president. It was be and not the national legislature that became the focus of public and media attention. Does he have the mettle needed? What will he do, and will his actions be sufficient to deal with the situation? These were the sort of questions being debated on the talk shows and in the press. To put it bluntly, at this moment, there was little interest in what the legislature might say or do, the mighty Congress, at this point at least, was reduced to a role comparable, dare it be said, to that

David Mervin is Reader in Politics in the Department of Politics and International Studies, University of Warwick, Coventry $\mathrm{CV}_{4} 7 \mathrm{AL}$.

${ }^{1}$ Helen Dewar "Iraq Fight Lasts Longer in the Senate Than It Did in the Persian Gulf," Washington Post, 7 Sept. 1996, p. A8. 
of the British House of Commons. The situation called for leadership and decisive action and no one was under any illusion that the legislature could provide either, only the president was in a position to meet these needs. When it comes to the making of foreign policy, and particularly when crises of national security arise, the president, it seems, is inevitably, the main player, the senior partner.

Such perceptions are, however, at considerable variance with the consensus that prevails in the academy on these matters. This was reaffirmed in an article published in the journal of the presidency research group of the American Political Science Association, shortly after the events outlined above. ${ }^{2}$ In this piece presidential supremacy in the making of foreign policy was reviled as being based on a "myth, relentlessly asserted over the past several decades, [that] has poisoned the minds of the press and the public." The Constitution it was averred "assigns to Congress senior status in a partnership with the president for the purpose of conducting foreign policy" and various historical precedents were cited to demonstrate the unconstitutionality of unilateral warmaking by the executive. Reference was made to the "postwar pattern of presidential usurpation of congressional powers" and Congress was denounced for failing to assert its "constitutional powers and responsibilities." The article concluded with: "at all events, the Constitution, properly understood and interpreted, does not sanction presidential domination of America's international affairs."

It is evident that there is a large disparity between how American foreign policy is actually conducted and the normative notions of most constitutional lawyers and political scientists. Of course, the existence of this alarmingly large gap has often been attributed to executive branch

2 David Gray Adler, "The Constitution and the Conduct of American Foreign Policy," PRG 18:2, (Fall 1996), I, 9-10. Among the many studies that can be included as part of the consensus are David Gray Adler and Larry N. George, eds., The Constitution and the Conduct of American Foreign Policy (Lawrence, Kan.: University of Kansas, 1996). Raoul Berger Executive Privilege: A Constitutional Myth (Cambridge, Mass.: Harvard University Press, 1974). Theodore Draper, A Very Thin Line: The Iran Contra Affair (New York: Hill and Wang, I99I). Louis Fisher, Presidental War Power (Lawrence, Kan. : University of Kansas, 1995). Louis Fisher, Constitutional Conflicts Between President and Congress (Princeton: Princeton University Press, 1985). Michael J. Glennon, Constitutional Diplomacy (Princeton: Princeton University Press, I990). Louis Henkin, Constitutionalism, Democracy and Foreign Affairs (New York: Columbia University Press, I 990). Edward Keynes, Undeclared War: Twilight Zone of Constitutional Power (University Park: Pennsylvania State University Press, 1982). Harold Koh, The National Security Constitution (New Haven: Yale University Press, 1990). Arthur Schlesinger Jr., The Imperial Presidency (London: Andre Deutsch, I974). Francis D. Wormuth and Edwin B. Firmage, To Chain the Dog of War and edn (Urbana: University of Illinois, 1989). 
machinations combined with the failure of Congress and the courts to do their duty, but there is surely more to it than that. ${ }^{3}$ It will be argued in this article that presidential supremacy in foreign policy making is inevitable and that that inevitability has long been accepted by the public, as well as most legislators and judges, even though it does not square with the intentions of the Founding Fathers.

\section{THE FOUNDING FATHERS}

The intentions of those who drew up the Constitution with regard to war making are, in fact, less clear cut than is sometimes suggested. ${ }^{4}$ It should be noted first of all that this was not a subject that engaged the attention of the Constitutional Convention for very long. ${ }^{5}$ The matter was briefly referred to at the beginning when the nature of the executive, whether it should consist of three persons or one, was discussed. Charles Pinckney of South Carolina favoured a "vigorous executive," but did not wish the new office to acquire the powers of "peace and war." This view was shared by his colleague from South Carolina, John Rutledge, and by James Wilson of Pennsylvania who preferred a single executive but, "did not consider the Prerogatives of the British Monarch as a proper guide in defining the executive powers. Some of these prerogatives were of a Legislature nature. Among others that of war and peace."

The only substantive discussion of the war power question appears to have occurred on 17 August 1787 when the Convention was reviewing the proposed powers of the legislature. ${ }^{7}$ The suggested clause "To make

${ }^{3}$ See, for example, Stephen Weissman, A Culture of Deference (New York: Basic Books, I995), Ch. I

4 The wise words of Justice Jackson on this matter provide a useful lesson. "Just what our forefathers did envision, or would have envisioned had they foreseen modern conditions, must be divined from materials almost as enigmatic as the dreams Joseph was called upon to interpret for Pharaoh. A century and a half of partisan debate and scholarly speculation yields no net result, but only supplies more-or-less apt quotations from respected sources on each side of any question. They largely cancel each other." Youngstown Sheet and Tube Co. v Sawyer, 343 US 579 (1952), 635-36.

${ }^{5}$ Louis Fisher suggests otherwise; see his Presidental W ar Power, 3-4. By contrast, Charles Lofgren points out that the allocation of the war power took up little more than one page of the 1,273 printed records of the Constitutional Convention. The same scholar also notes that these matters received little attention in the state ratification debates. "War-Making Under the Constitution: The Original Understanding," Yale Law Journal, 8I (1972), 672-702.

6 Max Farrand, ed., The Records of the Federal Convention of 1787 (Revised edition in four volumes) (New Haven: Yale University Press, 1937). Subsequently cited as Farrand, I, $65-6$.

7 Ibid., 2, 318-19. 
war" was one of six debated during a working day that normally extended from io to $4 .{ }^{8}$ Only one delegate, Pierce Butler of South Carolina, is recorded as having spoken in favour of vesting the power to make war in the executive, a view that was roundly rejected by Roger Sherman of Connecticut, Elbridge Gerry of Massachusetts and George Mason of Virginia. Gerry and James Madison of Virginia recognized, however, that simply placing the power to make war in the hands of the legislature would not suffice. They suggested that Congress be given the power to declare rather than make war "leaving to the executive the power to repel sudden attacks." In essence, this was to distinguish between offensive and defensive wars. The initiation of hostilities would normally require the agreement of the legislature, whereas the executive had to be provided with the discretion to deal with defensive emergencies as they arose. This was an eminently sensible position consistent with the need for national self-preservation, a central concern of the constitution makers as both Madison and Alexander Hamilton made clear. The former referred to "the great principle of self-preservation; to the transcendent law of nature and of nature's God, which declares that the safety and happiness of society are the objects at which all political institutions aim and to which all such institutions must be sacrificed." "Hamilton meanwhile stressed that "every government ought to contain in itself the means of its own preservation." Nevertheless, while the "repel sudden attacks" proviso made perfectly good sense, the long-term ramifications were profoundly consequential, as will later become apparent.

Those many scholars anxious to preserve the position of Congress in the making of foreign policy are inclined to emphasise the concerns expressed in the Convention about the possibilities of executive tyranny, yet, while such concerns were undoubtedly present, they were matched by a no less keen awareness of the danger of an overbearing legislature, prone to encroach on the other branches of government. At Philadelphia, Gouverneur Morris declared that "the public liberty (was) in greater danger from legislative usurpations than from any other source."10 Madison noted that "experience had proved a tendency in our governments to throw all power into the Legislative vortex." 11 He made the same point in Federalist No. 48, and went on to say that while tyranny was a real possibility in an hereditary monarchy it could also occur in

8 Ibid., 322.

9 The Federalist Papers (Introduction by Clinton Rossiter) (New York: New American Library, I96I), Federalist No. 43, p. $279 . \quad{ }^{10}$ Farrand, 2, 76.

11 Ibid., 2, 35. 
representative republics. ${ }^{12}$ In Federalist No. 71, Hamilton provides trenchant support for the belief that Congress is pathologically inclined towards constitutional empire building, constantly seeking to extend the area of its authority. He refers to the "tendency of the legislative authority to absorb every other" and goes on to argue that in republican governments such tendencies are unavoidable and destructive of balance in the constitution. ${ }^{13}$

Balance is surely the key word here. While those who drew up the Constitution were determined not to duplicate the British system with its potential for executive tyranny they were no less concerned to avoid the perils of the state constitutions with their rampant legislatures. It is also the case that one of the overriding considerations of the Founding Fathers was to effect a constitutional arrangement that, unlike the Articles of Confederation, provided for "energy" in government, a requirement that Madison believed to be as "essential to that security against external and internal danger and to that prompt and salutary execution of the laws which enter into the very definition of good government."14 Unsurprisingly, Hamilton took the same position while also identifying the executive as the repository for the energy indispensable to good government. "A feeble executive implies a feeble execution of the government. A feeble execution is but another phrase for a bad execution; and a government ill executed, whatever it may be in theory, must be, in practice, a bad government... all men of sense will agree in the necessity of an energetic executive." 15

Given these contentions it surely cannot be the case that the Framers wished to create an executive with powers as limited, or as lacking in "energy," as those of governors. ${ }^{16}$ It is true that Madison spoke in the Convention of governors being "little more than Cyphers," but it is necessary to consider the context in which that remark was made. He was against any movement towards monarchy, but deplored the fact that state executives were in the thrall of legislatures. The omnipotence of legislatures was not only undesirable, it was also potentially counterproductive for "If no effectual check be devised for restraining the instability and encroachments of (legislatures), a revolution of some kind or other would be inevitable. $" 17$

12 Federalist Papers, 309.

${ }^{13}$ Ibid., 433. Note The index to the Rossiter edition of the Federalist contains 6 references under "legislatures: their tendency to engulf other branches of the government."

14 Ibid., 226.

16 See David Adler and Larry George The Constitution and the Conduct of American Foreign Policy, pp. $197^{-98}$. ${ }^{17}$ Farrand, 2, 35. 
While the Founding Fathers were anxious to guard against executive tyranny they certainly did not favour a weak executive, deferential towards the legislature of the sort that pro-Congress scholars often seem to favour. Energy and strength were deemed to be essential requirements of good government. As Hamilton made clear, "servile pliancy" by the executive was not what was wanted; on the contrary it was "certainly desirable that the executive should be in a situation to dare to act his own opinion with vigor and decision." 18 The Framers, it is reasonable to conclude, envisaged a president who would be tough-minded and strong, ready and willing to defend his corner against the inevitability of encroachments on his constitutional position.

\section{REPELLING SUDDEN ATTACKS IN THE TWENTIETH CENTURY}

As I noted earlier, during the brief discussions in the Convention on the war power it was accepted that it would be necessary to concede to the president the power "to repel sudden attacks." The Framers were intent on guarding against the possibility of the executive unilaterally embarking on military action abroad, but understood that where there was an immediate, unforeseen attack on the United States itself, the principle of self-preservation demanded that the president be given the freedom to respond. The word "sudden" had particular significance; the executive had to be allowed to deal with emergencies, or crises which did not brook the long delays that 200 years ago, at least, attended the convening of the legislature. Yet, if it took weeks to get Congress together in that era, by the same token, major foreign powers, with hostile intent towards the US, would require many weeks to marshall their forces and to transport them across the Atlantic before mounting any sort of substantial assault. Repelling sudden attacks in those circumstances was likely to be concerned with skirmishes rather than large engagements, whereas the latter would make possible a lengthier and wider degree of consultation in determining a response; there would, in other words, be ample time to involve Congress in the decision-making.

In the late twentieth century by contrast, the power, indeed the responsibility, to repel sudden attacks takes on a profoundly different meaning. In the i8 30 s, Tocqueville could reasonably say "the United

\footnotetext{
18 Federalist Papers, $43^{2-3} 3$.
} 
States is a nation without neighbors. Separated from the rest of the world by the ocean, and too weak as yet to aim at the dominion of the seas, it has no enemies, and its interests rarely come into contact with those of any other nation of the globe." 19

To state the obvious. Tocqueville's picture is far removed from the realities of today. The United States now lives within a world that has become a global village, where neighbours and enemies abound. As a mighty superpower, the US has the biggest navy and one of the largest armies in existence. And, even in the post-Cold War era, it has military personnel stationed, in significant numbers, in more than thirty countries reflecting its the worldwide spread of interests and its participation in a vast array of treaties and agreements with other nations. ${ }^{20} \mathrm{~A}$ modern president, furthermore, sits at the hub of an ultra-sophisticated system of intelligence gathering that enables him to monitor closely threats to American interests that may be unfolding on the other side of the world. While Congress has its own sources of information, it has not the slightest hope of competing with the executive branch in this area. ${ }^{21}$ The legislature can hardly help deferring to the president's superior vantage point, even though, it should be emphasised, that superiority in information is no guarantee of sound judgment.

Technological progress in the development of weaponry has also helped to transform the executive's responsibility to guard against sudden attacks. Even 60 years ago, the degree of technological change since the age of sailing ships was massive, as FDR explained in a fireside address he made before the US entered World War II. He insisted that the nation was "mustering its men and its resources only for purposes of defense-only to repel attack ... But we must be realisic when we use the word 'attack', we have to relate it to the lightning speed of modern warfare... it would be suicide to wait until (foes) are in our front yard. When your enemy comes at you in a tank or a bombing plane, if you hold your fire until you see the whites of his eyes, you will never know what hit you. Our Bunker Hill

19 As cited in John Chubb and Paul Peterson, eds., Can the Government Govern? (Washington DC: The Brookings Institution, 1989), 20-2 I.

20 See "Active Duty US Military Personnel Strengths, Worldwide," Dept of Defense figures World Almanac and Book of Facts 1996, 163.

21 With reference to the president's information advantage in the modern age. according to one authoritative source, writing nearly a decade ago, no less than half a million cables a day were then passing to and from the executive branch and embassies and other overseas posts. Moreover, 25 miles of film were taken by US reconaissance aircraft over Cuba in one day during the Cuban Missile Crisis. Bradley H. Patterson Jr., The Ring of Power (New York: Basic Books, 1988), 48 and 66. 
of tomorrow may be several thousand miles from Boston." 22 And how far removed are we now from the age of Roosevelt? The introduction of intercontinental nuclear missiles was surely a further crucial stage in the creation of an extraordinarily dangerous world, far beyond anything that those infinitely wise Founding Fathers could have foreseen when they briefly discussed these matters in Philadelphia.

A reasonably neat distinction between offensive and defensive war may have been possible two centuries ago, whereas such distinctions are far less easily made today. The president, above all other public officials, has a particular responsibility to determine whether threats to the national security are developing elsewhere in the world. As Richard Neustadt aptly remarked, "When it comes to action risking nuclear war, technology has modified the Constitution: the President perforce becomes the only man in the system capable of exercising judgment under the extraordinary limits now imposed by secrecy, complexity and time." 23 Or, as Edward Keynes has put it, "The Framers intentions to the contrary ... there is no clear cut distinction between defensive and offensive warfare. In the twentieth century, extensive alliance systems, thermonuclear warfare, and supersonic delivery systems vitiate such eighteenth-century dichotomies." $" 24$

By inserting the "repel sudden attacks" qualification the Founding Fathers unwittingly set in train the eventual undermining of one of their principal objectives - the keeping of the war power out of the president's hands. The dangers inherent in the situation were eloquently and famously spelled out by Congressman Abraham Lincoln in a letter to his former law partner:-

Allow the President to invade a neighboring nation, whenever he shall deem it necessary to repel an invasion, and you allow him to do so, whenever he may choose to say he deems it necessary for such purpose - and you allow him to make war at pleasure. Study to see if you can fix any limit to his power in this respect... (If) he should choose to say he thinks it necessary to invade Canada, to prevent the British from invading us, how could you stop him? You may say to him, "I see no probability of the British invading us" but he will say to you "be silent; I see it, if you don't." (Italics in the original) ${ }^{25}$

As Lincoln understood, the Framers were anxious to ensure that the

${ }^{22}$ The Public Papers and Addresses of Franklin D. Roosevelt (New York: Russell and Russell, I 950), ro, I $88-89$.

23 R. Neustadt, Presidential Power and the Modern Presidents (New York: The Free Press, I990), I 80-8I. $\quad{ }^{24}$ Keynes, Undeclared $W$ ar, 40.

${ }^{25}$ Letter to William Herndon, is Feb. I 848, in Roy Basler, Abrabam Lincoln: His Speeches and Writings (New York: The World Publishing Co, 1959), $285-86$. 
initiation of an offensive war did not occur without consultation with Congress; it should not be left to the president "to make war at pleasure." However, given the massive involvement of the United States in the outside world, the "lightning speed of modern warfare" and the advanced forms of intelligence gathering now available, Lincoln's worst fears have been realized. It has now become appropriate for a president to say "The interests of the United States are under threat, and my duty demands that I take steps to counter that threat, even if other political leaders do not share my view that such a threat exists."

An hypothetical example may help to make the point. Assume for the sake of argument that a rogue state in possession of nuclear missiles has launched such a missile and it is, at this moment, in the air en route to the US mainland. Defensive radar installations will have alerted the president to the presence and direction of the missile and it will be incumbent upon him to decide what to do, and quickly. Of course, once the missile has struck, his constitutional position is eminently clear; a sudden attack has occurred which he is fully entitled to repel. But by then devastation is likely to have taken place and the strategic situation may have become irretrievable. Surely common sense demands that the president be allowed to respond to any attack as soon as he is aware of its initiation and not after it has taken place. The exigencies of modern warfare may well preclude the possibility of comparing notes with Congress in such circumstances. And even if consultation with Congress was possible, and the legislature drawing on its sources of information, denied that an attack was in train, the president would be duty bound to say, "Be silent: I see [the danger], if you don't."

It is, moreover, difficult to detect any logical distinction between the above scenario and a president launching an attack against an airfield from which he believes an assault on the US is to be mounted sometime soon. Unlike their early predecessors, chief executives today must be alert to sudden attacks not just at the nation's borders, but also to those that may be developing many miles away. Unpalatable though it undoubtedly is to constitutional purists, the "repel sudden attacks" doctrine, in its modern guise, appears to legitimize pre-emptive strikes.

On reflection, it seems to me that the appearance of aircraft capable of launching attacks across the Atlantic within hours, is an insufficiently recognized stage in American constitutional development. This was a watershed, the beginning of new era, where nothing would ever be the same again and where the constitutional sanctity of the war power as envisaged by the Framers could no longer be upheld. The onset of 
presidential dominance in war making dates not from World War II, the I950s, or the Vietnam conflict, but from the invention of long range military aircraft.

There is no doubt that the Founding Fathers intended, as far as possible, to keep the war power out of the hands of the executive, but they recognized that that restriction could not reasonably be absolute. Their intentions however, provide only a starting-place for the discussion of these matters rather than a conclusion. ${ }^{26}$

\section{THE QUESTION OF PRECEDENTS}

In a nation with a written constitution precedents assume a particular importance, but it is necessary to consider which precedents need to be taken into account? Staunch defenders of the rights of Congress in these matters are, not surprisingly, drawn to early precedents as is evident from a recent volume of essays by some distinguished scholars. ${ }^{27}$ In a section of the book devoted to "historical perspectives and precedents" there are 5 chapters, 4 of which are concerned with events in the administrations of Washington, John Adams, and Jefferson. If the analysis is restricted in this way to the early years of the republic, it is not difficult to argue the case for congressional dominance in the making of foreign policy, whereas two centuries on the considerations discussed in the previous section have brought about a metamorphosis with profound consequences for the Constitution.

What is at issue here is more than a question of constitutional law; this matter is not to be disposed of by focussing on legalisms alone, or on precedents narrowly defined in the manner of lawyers. A precedent in this context is "something done or said that may serve or be adduced as an example, reason or justification for a subsequent act of a like kind." It is also "something which comes down to us from the past with the sanction of usage and common consent." 28

It is precedent used in these senses that is relevant to the argument

${ }^{26}$ Charles Lofgren, "War-Making," sensibly concludes his analysis with: "Whether the original understanding properly concludes the issue undeniably involves questions quite different from those I have here discussed. Still, paying it some heed is surely consonant with a devotion to constitutionalism."

27 Adler and George, The Constitution.

28 Both of these definitions are from Webster's New Twentieth Century Dictionary of the English Language (unabridged, 2nd edn) (Cleveland: The World Publishing Company, I960), I4 I6. 
being advanced in this paper. In short, it is evident that a whole succession of presidents have assumed the right to take action in response to threats to the national security without going through the processes of consultation that a close reading of the Constitution would seem to demand. These actions, moreover, have generally been approved, or, at least been acquiesced in, by other political leaders, and by the public in general. To put it another way, the notion that when crises or emergencies arise the chief executive is entitled, if not duty bound, to take action as he sees fit without deferring unduly to legislators or judges, has become embedded in the American political culture.

No one has been more important in providing a role model and a justification for such acts than Abraham Lincoln. The Civil War remains "the most dangerous emergency ever faced by a government of the United States" and that harrowing sequence of events is notable for the extraordinary assumptions of power by Lincoln in order to meet an undeniably desperate situation. ${ }^{29}$ As Clinton Rossiter has said of Lincoln "The important fact is that he assumed unprecedented authority on his own initiative, that he was supported in this radical conduct by the majority of public opinion, and that he thereby saved the Union and set a consequential historical precedent for all future crises in this or any other democracy." 30

Under the press of Civil War Lincoln, as is well-known, embarked on a whole series of actions of dubious constitutionality. In his proclamation of is April i86i, he pronounced that Congress would not be convened until July 4th, a manoeuvre patently designed to preserve the president's freedom to deal with the rebellion "without the vexatious presence of an unpredictable Congress to confuse the narrow issue." 31 Before Congress could have an opportunity to deliberate, Lincoln had blockaded southern ports; massively expanded the armed services; directed the Secretary of the Treasury to transfer unappropriated funds to private citizens; suspended the writ of habeas corpus and set in train arbitrary procedures for dealing with those allegedly engaged in treasonable activity. ${ }^{32}$ These and

29 Clinton Rossiter, Constitutional Dictatorship (Princeton: Princeton University Press, 1948), $223 . \quad 30$ Ibid., $224 . \quad 31$ Ibid., 226.

32 The fact that Congress legitimized some of these actions after the event hardly disposes of the fact that by declining to convene the legislature immediately Lincoln effectively sidelined that body in the early months of the war. See Donald Robinson, "Presidential Prerogative and Constitutionalism"; Adler and George, i 8 . It is also notable that Lincoln claimed during the war that "I conceive that I may in an emergency do things on military grounds which cannot be done constitutionally by Congress." As quoted in David Herbert Donald, Lincoln (New York: Simon and Schuster, I 995), 5 I I. 
various other constitutionally suspect actions taken by Lincoln during the war were justified in the name of a dire emergency that put at risk the very preservation of the state. ${ }^{33}$

Doubts as to the constitutionality of Lincoln's various responses to the crisis clearly troubled some members of the judiciary at the time. The blockading of southern ports was upheld by the Supreme Court by a majority of only 5-4; Chief Justice Roger Taney denied the president's authority to suspend the writ of habeas corpus in the Merryman case and the Court decided against Lincoln in Ex parte Milligan two years after his death. ${ }^{34}$ However, as Corwin said with regard to the latter decision "To suppose that such fustian would be of greater influence in determining presidential procedure in a future great emergency than precedents backed by the monumental reputation of Lincoln would be merely childish. " 35

Corwin was surely absolutely right. There can hardly be a figure in American history more widely respected than Abraham Lincoln. He is the subject of a cult, an heroic figure revered for displaying masterly qualities of leadership and for doing what had to be done during the nation's gravest crisis. ${ }^{36}$ And the fact that he showed scant regard for the Constitution in meeting the challenges he faced and in setting immensely important precedents, is not seen as in any way detrimental to his high reputation.

33 A number of scholars have cast doubt on the relevance of the Lincoln precedent for foreign affairs. Thus one argues that Lincoln's wartime presidency did not disturb the original intentions of the Framers for he "had not exercised his power in foreign affairs ... instead he had expansively employed his domestic statutory and constitutional powers." Harold Koh, The National Security Constitution, 8 5. Another student of these matters takes a similar, although slightly different, line in saying that "none of Lincoln's actions constitutes a precedent for presidential initiation of war. The attack on Fort Sumter represented a 'sudden attack' that Lincoln had the constitutional power to repel." David Adler, "The Constitution and Presidential War-Making," in Adler and George, 206-7. Both of these responses however, demand that Lincoln's actions be viewed in a narrowly legalistic sense, whereas I am arguing that they need to be seen in a broader context. Obviously, the emergency faced by Lincoln was not, as such, concerned with foreign policy; in the terminology of that era it was a crisis of public safety, but, whatever the wording, this was an emergency threatening the very existence of the state and it was, therefore, directly comparable to a modern crisis of national security. The parallels between the Civil War and the Cuban Missile Crisis, for example, are, in that sense, close. My position is similar to that of Rossiter, passim. See also Hugh Gallagher, "Presidents, Congress and the Legislative Functions," in Rexford Tugwell and Thomas Cronin, eds. The Presidency Reappraised (New York: Praeger, 1974), 223.

${ }^{34}$ Prize Cases (1862), ex parte Merryman (1861) ex parte Milligan (I866).

35 Quoted in Rossiter, 238.

${ }^{36}$ For Lincoln as a cult figure see Ralph Gabriel The Course of American Democratic Thought (New York: The Ronald Press, 1956), 445-50. 
In the pantheon of American heroes, Franklin Roosevelt stands not far behind Lincoln and shared with him that propensity to do what needed to be done in times of crisis without worrying unduly about the concerns of constitutional purists. ${ }^{37}$ As we have seen, FDR took the view that chief executives in the modern world had to be alert not just to immediate threats at the nation's borders, but also to those that might be developing half a world away. Thus, in the late i930s, he observed with increasing alarm the unchecked advance of the Third Reich in Europe and repeatedly warned the American people that they could not afford to ignore what was happening on the other side of the Atlantic. Nevertheless, prior to the attack on Pearl Harbor at least, Roosevelt's freedom to act was constrained by the powerful aversion to foreign entanglements that persisted in Congress and among the people. The reluctance of legislators to see the United States get involved in the war even as late as I94I, is reflected in the famous 203-202 vote in the House of Representatives to approve an extension of the draft. Likewise, the lack of enthusiasm among the public for intervention was shown by innumerable public opinion polls. One taken on 17 Sept. I94I, two years after hostilities had begun between Britain and Germany, had 87 percent of Americans answering in the negative to the question "Should the United States go into the war now and send an army to Europe to fight." 38

FDR was, accordingly, obliged to move with stealth in 1940 and I94I, concealing his true purposes and often acting in a manner contrary to the letter and the spirit of the Constitution. Thus the exchange of American destroyers for British bases, the despatch of troops, first to Greenland and then, much more controversially, to Iceland, were all put into effect by executive agreements. These and other actions by Roosevelt such as the issuing of "shoot on sight" orders to navy ships escorting convoys in the Atlantic, and the signing of the Atlantic Charter with its reference to Nazi tyranny, were hardly consistent with the official American policy of neutrality.

The crux of Roosevelt's strategy at this point was support for the British. He had determined that if Britain, and its navy, fell into German hands the United States would become fatally vulnerable. By acting in the way that he did, he could be said to be meeting his responsibility to "repel

${ }^{37}$ For the Roosevelt legend see William Leuchtenburg, In the Shadow of FDR (Ithaca: Cornell University Press, I983).

38 Hadley Cantril, Public Opinion 1935-1946 (Princeton: Princeton University Press, 195 I), 976. 
sudden attacks" even though many members of Congress and other opinion leaders vehemently disagreed with his diagnosis and deplored his chosen course of action. ${ }^{39}$

Lincoln and Roosevelt are two giants of American history whose presidencies have been lavishly lauded by historians and media commentators alike, while among the public they are perceived as truly great men. They have, in other words, the status of cultural icons and, as such, they set precedents of enduring importance for the exercise of power by presidents in crisis situations. It can be said of each as Rossiter said of Lincoln "What he did, not what the Supreme Court said, is the precedent of the Constitution in the matter of presidential emergency power." 40

To read some of the academic commentary on the war powers question it hardly seems possible that few presidents in the twentieth century have adopted anything but an expansive view of the power of the executive when it comes to the making of foreign policy. For fundamentalists, Theodore Roosevelt provides a particularly brazen example, constantly treating Congress with the greatest contempt, and, on leaving office, exulting in his virtually one man conduct of foreign affairs: "The biggest matters such as the Portsmouth peace, the acquisition of Panama, and sending the fleet around the world, I managed without consultation with anyone: for when a matter is of capital importance, it is well to have it handled by one man only." 41

Woodrow Wilson's view of the foreign policy role of the president was no less expansive than TR's, although unlike his great rival Wilson offered a theoretical justification for his behaviour. "When foreign affairs play a prominent part in the politics and policy of a nation, its executive must of necessity be its guide: must utter every initial judgment, take every first step of action, supply the information upon which it is to act, suggest and in large measure control its conduct." ${ }^{42}$ One scholar has, however, discounted the examples of Roosevelt and Wilson on the grounds that their wide-sweeping notions of their authority in foreign affairs were not accepted by their successors "uncritically as either constitutional orthodoxy or as guides to action. " 43 Perhaps it all depends on what is

39 Among the public figures vigorously dissenting were Charles Beard, Charles Lindbergh and Claire Booth Luce. $\quad{ }^{40}$ Constitutional Dictatorship, 238-39.

41 As quoted in Arthur Schlesinger Jr., The Imperial Presidency, 89; Note: Speaker Cannon said of Roosevelt "he's got no more use for the Constitution than a tom cat has for a marriage license." Edmund Morris, The Rise of Theodore Roosevelt (New York: Ballantine Books, i 979), i I.

42 Congressional Government (Boston: Houghton Mifflin, I885 and I913), Preface to i 5 th edn, Is Aug. I900, xix-xx. $\quad{ }^{43}$ Koh, The National Security Constitution, 91. 
meant by "successors" but certainly almost all of those who have succeeded TR and Wilson in the White House have entertained much the same view of their responsibilities in the making of foreign policy. The most obvious example, Franklin Roosevelt, has already been discussed, a man who, incidentally, managed to be both a Wilson disciple and a devoted admirer of his cousin Theodore. ${ }^{44}$

As I have noted, FDR manoeuvred to meet the threat from Nazi Germany without worrying unduly about constitutional niceties in doing so. And then, even before the US entered World War II, the same president began the process which led eventually to the creation of the atomic bomb. This involved the expenditure of massive amounts of money without congressional authorisation on a project fraught with constitutional ramifications. Ultimately, the outcome was one of the most significant foreign policy decisions of all, made by Roosevelt's successor, again without any consultation with Congress whatsoever, the decision to drop the bomb. It is difficult to see how these momentous decisions can be reconciled with a close reading of the Constitution, and yet few would deny that both Roosevelt and President Truman were obliged to deal with these matters as they did.

And so it has gone on; Theodore Roosevelt citing Lincoln, Wilson following TR's examples and FDR inspired by his two eminent predecessors. It was hardly surprising that some years later John Kennedy should feel free at the time of the Cuban Missile Crisis to embark on military action in extraordinarily dangerous circumstances without consulting with Congress. The fact of the matter is that almost every president in the twentieth century has firmly refused to accept the fundamentalist interpretations of the constitution with regard to foreign policy-making so beloved of political scientists and constitutional lawyers; moreover, these interpretations have also been consistently regarded without enthusiasm by most members of Congress, by the courts and by the public at large.

Over and over again, in this century particularly, presidents in taking military action have not adhered to the original intent of the Founding Fathers. Even in recent decades, despite the reaction against the war in Vietnam, the "horrors" of the imperial presidency and the passage of the War Powers Resolution, presidents have continued to act as if the "war

${ }^{44}$ FDR worked for Wilson's nomination in I9 12 and served in his administration. His lavish admiration for TR is fully documented in Geoffrey Ward, A First Class Temperament: The Emergence of Franklin Roosevelt (New York: Harper and Row, I989), passim. 
power" belongs to them. From Grenada to Panama, the Gulf, Somalia, Haiti and Bosnia presidents have gone on using military force without due regard for the Constitution. Yet, while scholars complain vociferously, and there are occasional mutterings on Capitol Hill, the fact remains that legislators and judges habitually go along with these digressions. The general public meanwhile remains generally unperturbed continuing to support in public opinion polls and elections presidents who stand accused of flagrantly violating the Constitution in their scant respect for the role of Congress when it comes to decisions to embark on military action. ${ }^{45}$

The consistent widespread acquiescence in the technically unconstitutional behaviour of presidents in such matters is not to be explained simply as resulting from the failure of legislators and judges to do their duty; nor can it reasonably be attributed to the peddling of myths that have "poisoned the minds of the press and the public." 46 Given the torrent of precedent, in the twentieth century particularly, it surely is the case that the Constitution has effectively been "adapted by usage." This is not so much a matter of legalisms but of political culture. Both elites and the mass public now accept that presidents must be allowed a degree of discretion in coping with national security crises. No doubt this is at odds with the original intentions of the Framers, but it more closely meets the realities of a modern dangerous world.

There is also the matter of prerogative to be considered. Despite the ominous consequences for democratic government some eminent authorities have argued that in emergency situations, where the preservation of the state is at stake, executives may legitimately act outside the law. Prerogative was invoked by Lincoln when he said during the Civil War:

my oath to preserve the Constitution to the best of my ability imposed upon me the duty of preserving, by ever indispensable means that government - that nation, of which that Constitution was the organic law... I felt that measures otherwise unconstitutional might become lawful by becoming indispensable to the preservation of the Constitution through the preservation of the nation. ${ }^{47}$

Some have argued that prerogative is part of the power of the executive under the Constitution, whereas others have seen it as an extra-

45 Richard Pious notes the wildly enthusiastic reception accorded Colonel Oliver North by the public at the Iran Contra Committee hearings: "the people embrace North as a national hero," "Prerogative Power and the Reagan Presidency: A Review Essay," Political Science Quarterly, I06:3 (Fall I991), 499-5 I0. ${ }^{46}$ See p. 484 above.

47 Jay Shafritz, American Government and Politics (New York: Harper Collins, I993), 379. 
constitutional power. ${ }^{48}$ However, leaving aside these complexities a number of democratic theorists have given their support to the idea of prerogative. Most famously John Locke, when he argued that in some situations the national interest requires that "the laws themselves... give way to the executive power... This power to act according to discretion for the public good, without the prescription of law and sometimes even against it, is that which is called 'prerogative'." 49

Similarly, Thomas Jefferson gave powerful voice to chief executives presuming to venture outside the law in defence of the security of the nation:

A strict observance of the written law is doubtless one of the high duties of a good citizen, but it is not the highest. The laws of necessity, of self-preservation, of saving our country when in danger, are of higher obligation. To lose our country by a scrupulous adherence to written law, would be to lose the law itself, with life, liberty property and all those who are enjoying them with us; thus absurdly sacrificing the end to the means. ${ }^{50}$

This is surely an unanswerable argument. However much the rule of law and the sanctity of the Constitution are cherished, in some circumstances they have to take second place to the ultimate purpose of government, the preservation of the nation and the safety of its people. Not only Locke and Jefferson, but also Rousseau and John Stuart Mill are included among the great luminaries of democratic political thought who have contributed to prerogative theory; its philosophical justification, in other words, is an important part of western culture. ${ }^{51}$

I began this article by contrasting how American foreign policy is conducted in practice with the theoretical musings of academicians. I accept that the majority of scholars are right in their insistence that the Founding Fathers were bent on denying the president the power to make war, even though they were obliged to accept that he must be allowed to repel sudden attacks. But, if the Framers were anxious to hobble the president when it came to war-making, the dangers of executive tyranny were not their only concern. They were equally worried by the propensity of legislators to encroach on other branches and sought an arrangement

48 See Robert Scigliano "The President's 'Prerogative Power,'” in Thomas Cronin, ed., Inventing the Presidency (Lawrence, Kansas: University Press of Kansas, 1989), 236-56.

49 The Second Treatise of Government, Thomas Peardon, ed., (New York: The Liberal Arts Press, I952), para I 59.

50 Thomas Jefferson to John B. Colvin, 20 Sept. I 8 10 in Thomas Jefferson: Writings (New York: The Library of America, I984), I 23 I.

${ }^{51}$ See J. Malcolm Smith and Cornelius P. Cotter, Powers of the President During Crises (Washington DC: Public Affairs Press, 1960), Ch. 3. 
that made for balance between them. They wanted, in other words, to ensure that, while the new government was restrained, it nevertheless possessed the energy that good government demanded; the executive moreover, was seen as the chief repository of that energy.

It has also been argued above that, notwithstanding the original intent of those who formulated the Constitution, changes in the international context in combination with the forces of technological development have transformed the situation. ${ }^{52}$ The age-old distinction between offensive and defensive war is no longer sustainable and the president's responsibility to repel sudden attacks now gives legitimacy even to pre-emptive strikes. The precedents set by Lincoln in the Civil War, the idea of prerogative, the introduction of long range military aircraft, the expansive approaches of foreign policy making by TR and Wilson subsequently built upon by Franklin Roosevelt - all of these factors help us to understand why Americans in the twentieth century have come to accept that, despite what the Constitution says, the president must be allowed to deal with national security crises as he sees fit, in the short term at least. However undesirable such attitudes may be to constitutional lawyers, the fact of the matter is that they are now deeply embedded in the American political culture.

As matters stand, when it comes to decisions regarding the use of military force, there is a large, longstanding gap between constitutional theory and what actually occurs in the real world. When national security crises arise, presidents are often obliged to become law-breakers, in a technical sense at least. That this is an undesirable state of affairs cannot be denied for as Justice Brandeis said: "If Government becomes the lawbreaker, it breeds contempt for the law; it invites every man to become a law unto himself; it invites anarchy." 53

So, how is the gap between theory and practice to be closed? It makes little sense, in my view, to insist, as so many scholars do, that the answer lies in greater vigilance by Congress and the Courts. There is no going back to the original intentions of the Framers; the situation of the United States in the world has changed too profoundly and there has been too much technological development. There have also been too many precedents and too much support for unilateral presidential war-making for that. The time has perhaps come when serious consideration may have

52 The very presence of that aide, never far from the president's side, clutching the attaché case containing the codes required for the launching of nuclear missiles is surely evidence in itself of circumstances far removed from anything that the Framers could have envisaged. $\quad{ }^{53}$ Quoted in Schlesinger, Imperial Presidency, 266. 
to be given to the implications of the comment made by another eminent jurist, Justice Arthur Goldberg, who said, "If our Constitution does not adequately permit what has to be done in a modern age to protect our security, our Constitution ought to be amended to permit it." ${ }^{54}$

54 As quoted in Berger, Executive Privilege, 100. 